'Laboratôrio de Genética e

Biotecnologia Microbiana (LGBM), Unidade Acadêmica de Garanhuns (UAG), Universidade Federal Rural de Pernambuco (UFRPE), Av. Bom Pastor, s/n, Boa Vista, CEP 55296-901,

Garanhuns, PE, Brasil

2Departamento de Agronomia

Universidade Federal Rural de

Pernambuco (UFRPE), Recife, PE, Brasil

*autor correspondente

凶andreza_quel@yahoo.com.br

\title{
Promoção de crescimento vegetal de feijão comum por bactérias isoladas de cana-de-açúcar
}

\author{
Plant growth promotion of bean by bacteria \\ isolated from sugarcane
}

Andreza Raquel Barbosa de Farias ${ }^{1 *}$, Danubia Ramos Moreira de Lima ${ }^{1}$, Luana Lira-Cadete ${ }^{1}$, Andresa Priscila de Souza Ramos ${ }^{1}$, Maria Camila de Barros Silva ${ }^{1}$, Fernando José Freire² Júlia Kuklinsky-Sobral ${ }^{1}$

RESUMO: O trabalho objetivou avaliar a variabilidade genética e o efeito de bactérias com características envolvidas na promoção de crescimento vegetal sobre o desenvolvimento de feijão comum (Phaseolus vulgaris). Foram avaliadas 10 linhagens bacterianas fixadoras de nitrogênio, solubilizadoras de fosfato inorgânico e produtoras de ácido indolacético, isoladas de cana-de-açúcar, quanto à variabilidade genética pela técnica de ARDRA e ao efeito no desenvolvimento de plantas de feijão comum. Foi observado efeito positivo sobre a massa fresca e seca da raiz de plantas de feijão por meio do tratamento de cinco diferentes bactérias. Em relação à parte aérea das plantas, foi observado que nenhum tratamento apresentou efeito positivo. As bactérias apresentaram alta variabilidade, sugerindo pertencerem a gêneros diferentes. Portanto, os resultados indicam que bactérias isoladas de determinadas plantas hospedeiras podem ser exploradas para utilização como inoculantes em outras espécies vegetais.

PALAVRAS-CHAVE: ARDRA, auxina, bactérias promotoras de crescimento vegetal, fosfato, nitrogênio, Phaseolus vulgaris.
ABSTRACT: This study aimed to evaluate the genetic variability and the effect of bacteria with characteristics involved in the plant growth promotion on the development of common bean (Phaseolus vulgaris). Ten nitrogen-fixing, inorganic phosphate solubilizing and indole acetic acid producing bacterial strains, isolated from plants of sugarcane were evaluated in regards to genetic variability by ARDRA technique and the effect on the development of bean plants. Positive effect was observed on the root fresh and dry weight of bean plants through the treatment of five different bacteria. Regarding the aerial parts of plants, it was possible to observe that no treatment produced positive effect on both fresh and dry weight. Bacteria showed high variability, suggesting they belong to different genus. Therefore, the results indicate that bacteria isolated from certain host plants can be exploited as inoculants for use in other plant species.

KEYWORDS: ARDRA, auxin, nitrogen, Phaseolus vulgaris, phosphate, plant growth-promoting bacteria.

Os mecanismos de interação bactéria-planta envolvem vários processos, como, por exemplo, a promoção de crescimento vegetal. Neste contexto, as bactérias promotoras de crescimento em plantas (BPCPs) são aquelas que se encontram em hábitats naturais, colonizando de forma interna e externa órgãos e tecidos vegetais (COMPANT; CLÉMENT; SESSITSCH, 2010). Entre os fatores que influenciam o crescimento vegetal, encontra-se a fixação biológica de nitrogênio por bactérias, como uma das mais relevantes, pois o nitrogênio é um macronutriente limitante do crescimento vegetal (BODDEY et al., 1992). Outro 
importante mecanismo é a solubilização de fosfato inorgânico por bactérias associadas às plantas, pois, apesar dos solos agrícolas possuírem grandes reservas de fósforo, a maior parte do fósforo inorgânico, na forma solúvel, é adsorvido logo após a aplicação de adubos fosfatados, tornando-se indisponível às plantas (GYANESWAR et al., 2002). Além desses, a produção de ácido indolacético (AIA), um regulador de crescimento vegetal da classe das auxinas, quando secretado por bactérias, também pode promover o crescimento da raiz diretamente através de estímulos que podem promover a elongação da célula vegetal ou divisão celular (PATTEN; GLICK, 2002).

As BPCPs apresentam elevada diversidade e os benefícios esperados a partir de melhor conhecimento sobre a diversidade microbiana são extensos (TILAK et al., 2005; COMPANT; CLÉMENT; SESSITSCH, 2010). Neste aspecto, vários estudos têm explorado a diversidade de bactérias associadas às plantas, obtendo-se novas informações para o conhecimento de mecanismos envolvidos na interação bactéria-planta (KUKLINSKY-SOBRAL et al., 2004; ANDREOTE; LACAVA; AZEVEDO, 2008). Nos textos científicos de diversidade genética, comumente têm-se utilizado diferentes técnicas para avaliar o genoma bacteriano com base nas diferenças das sequências de nucleotídeos de genes específicos ou aleatórios, como, por exemplo, ARDRA (Amplified Ribosomal DNA Restriciton Analysis), AFLP (Amplified Fragment Length Polymorphism), BOX-PCR (amplificação dos elementos BOX, sequências palindrômicas extragênicas repetitivas) e RAPD (Random Amplification of Polymorphic DNA), que permitem diferenciar os micro-organismos por nível de gênero e espécie, além de permitir a realização de correlações entre ambiente estudado e genótipo bacteriano (ANDREOTE; LACAVA; AZEVEDO, 2008).

O feijão comum, Phaseolus vulgaris, é uma leguminosa que apresenta alto teor proteico em sua total composição. Está presente na dieta de enorme parcela da população mundial, em especial nos países em que o consumo de proteína animal é limitado, por razões econômicas ou religiosas e culturais. No Brasil, é a principal leguminosa fornecedora de proteínas, fazendo parte da dieta diária das classes socioeconômicas menos favorecidas (MESQUITA et al., 2007). Logo, tratando-se de uma leguminosa, uma contribuição para o aumento da produtividade desta cultura seria a colonização dos nódulos por estirpes bacterianas eficientes, na fixação biológica do nitrogênio, e competitivas em relação à população nativa (XAVIER et al., 2006). Contudo a busca por bactérias promotoras de crescimento de plantas, que não pertençam à classe dos rizóbios, também poderá ser uma alternativa para o aumento da produção dessa cultura.

Diante do exposto, o presente trabalho teve por objetivo avaliar a variabilidade genética e o efeito de bactérias com características envolvidas na promoção de crescimento vegetal, isoladas de plantas de cana-de-açúcar, sobre o desenvolvimento de feijão comum (Phaseolus vulgaris), em casa de vegetação.

Foram utilizadas 10 linhagens de bactérias associadas a plantas de cana-de-açúcar, pertencentes à coleção de culturas bacterianas do LGBM/UFRPE. Essas bactérias apresentam a capacidade de fixar nitrogênio, solubilizar fosfato inorgânico e produzir ácido indolacético (AIA), in vitro, como está apresentado na Tabela 1.

As linhagens bacterianas foram repicadas em placas de Petri contendo meio TSA (Trypcase Soy Agar), para obtenção de colônias isoladas. Em seguida, colônias isoladas foram inoculadas em $5 \mathrm{~mL}$ de -TSA líquido e incubadas por 24 horas sob agitação constante $(150 \mathrm{rpm})$. As culturas foram diluídas em tampão PBS (Phosphate Buffered Saline) (KUKLINSKY-SOBRAL et al., 2004) para obtenção de inóculos em torno de $10^{6} \mathrm{UFC} / \mathrm{mL}$. Sementes de feijão comum, tipo carioca, coletadas na safra de 2010 no município de Garanhuns,PE, foram incubadas com a suspensão bacteriana ou em tampão PBS (controle) por 1 hora sob agitação (150 $\mathrm{rpm}$ ), resultando em 10 isolados bacterianos e mais um grupo controle, totalizando 11 tratamentos (Tabela 1). Em seguida, foram plantadas 3 sementes por sacos de polietileno, contendo $1 \mathrm{~kg}$ de substrato (Plant Max Hortaliças, Eucatex), com 10 repetições para cada tratamento, em delineamento inteiramente casualizado. Os sacos foram mantidos em casa de vegetação, sendo efetuada a manutenção hídrica diariamente, durante 30 dias. As plantas foram coletadas e aferiu-se a massa fresca e seca da parte aérea e da raiz. Para a análise da variabilidade genética bacteriana, o DNA genômico bacteriano foi extraído com a utilização do Genomic DNA Purification Kit (Fermentas), de acordo com as recomendações do fabricante. A amplificação do $16 \mathrm{~S}$ rDNA e a técnica de ARDRA (Amplified Ribosomal DNA Restriciton Analysis), utilizando as enzimas de restrição MboI e BsuRI (Fermentas), foram realizadas de acordo com Kuklinsky-Sobral et al. (2004).

No presente trabalho, quando avaliada a massa fresca da raiz, foi observado que o tratamento T9 (linhagem UAGC636) apresentou maior influência positiva comparada às demais (Figura 1a). A linhagem UAGC636, como apresentado na Tabela 1, apesar de não apresentar índice de solubilização de fosfato inorgânico (IS) igual ou superior a dois, índice que, segundo a literatura, é dito como ideal para bactérias

Tabela 1. Linhagens bacterianas isoladas de plantas de cana-de-açúcar.

\begin{tabular}{ccccc}
\hline Tratamentos & Linhagem* & CFN & IS & AIA \\
\hline Controle & Sem inoculação & - & - & - \\
\hline T1 & UAGC521 & + & 1,60 & +++ \\
T2 & UAGC523 & + & 1,27 & + \\
T3 & UAGC534 & + & 1,36 & + \\
T4 & UAGC536 & + & 1,63 & + \\
T5 & UAGC555 & + & 1,47 & + \\
T6 & UAGC560 & + & 1,50 & + \\
T7 & UAGC562 & + & 1,33 & + \\
T8 & UAGC563 & + & 1,91 & + \\
T9 & UAGC636 & + & 1,67 & + \\
T10 & UAGC667 & + & 1,56 & ++ \\
\hline
\end{tabular}

*Todas as linhagens apresentam a capacidade de fixar nitrogênio (CFN), solubilizar fosfato inorgânico, com índices de solubilização (IS) diferentes, e produzir ácido indolacético (AIA) em diferentes intensidades. (+++ Alta; ++ Média; e + Baixa produção de AIA) 


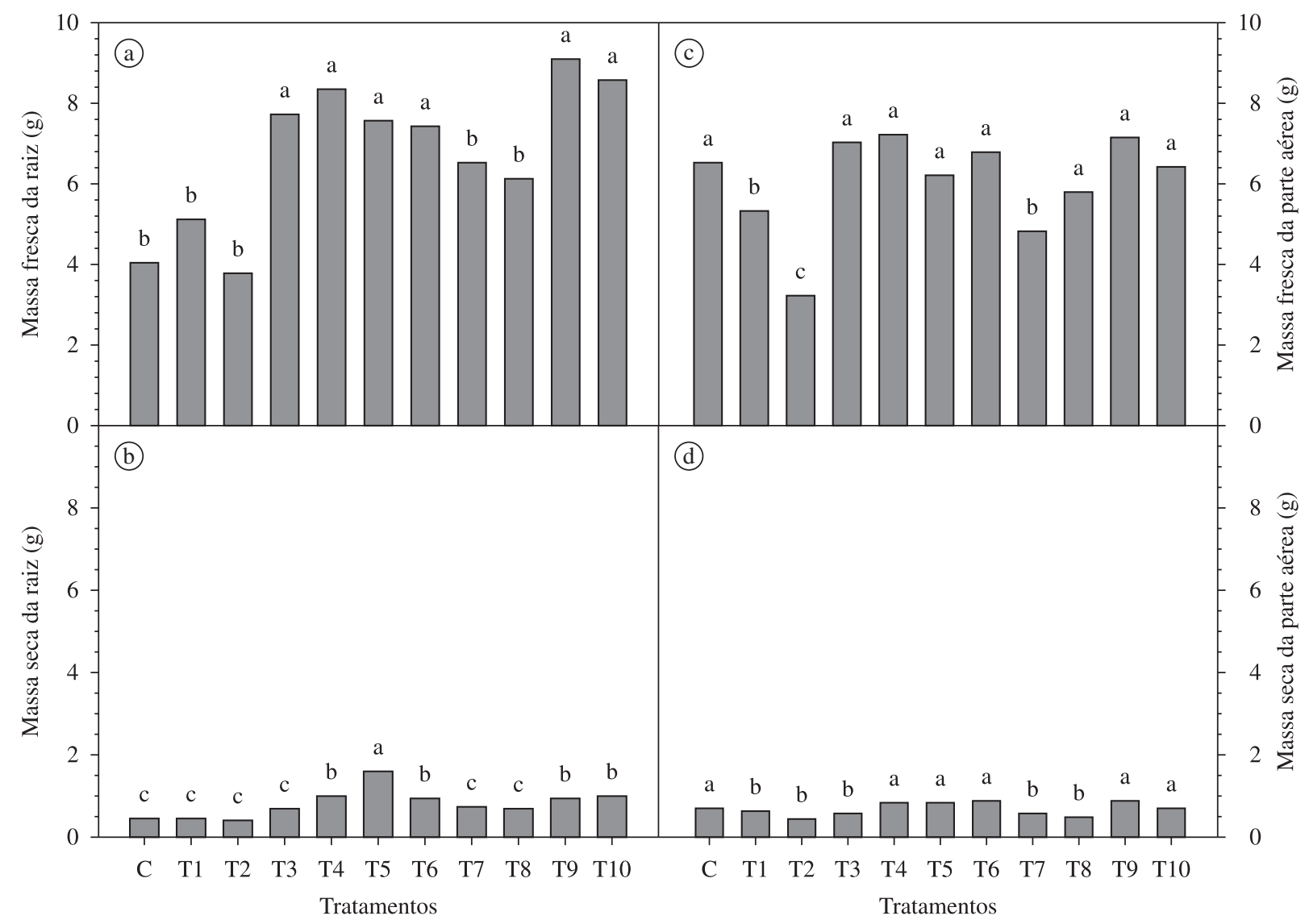

Figura 1. a) Massa fresca e b) massa seca de raízes; e c) massa fresca e d) massa seca da parte aérea de plantas de feijão comum submetidas a diferentes tratamentos*. As médias seguidas pela mesma letra não diferem estatisticamente entre si, pelo teste de Scott Knott $(\alpha=5 \%)$. *ontrole (sem inoculação); T1 (UAGC521); T2 (UAGC523); T3 (UAGC534); T4 (UAGC536); T5 (UAGC555); T6 (UAGC560); T7 (UAGC562); T8 (UAGC563); T9 (UAGC636 ); T10 (UAGC667).

promotoras de crescimento vegetal (SILVA FILHO; VIDOR, 2000), assim como a produção de AIA, que na classificação colorimétrica apresentou baixa produção, foi capaz de estimular o desenvolvimento do feijoeiro. Além desse tratamento, os tratamentos 3, 4, 5, 6 e 10 também apresentaram efeito positivo sobre a massa fresca da raiz, comportando-se estatisticamente superior à testemunha e aos demais tratamentos. Na massa seca da raiz, o destaque foi para o tratamento T5, no qual foi usada a linhagem UAGC555, juntamente com os tratamentos 4, 6 , 9 e 10, ressaltando-se que estes 5 tratamentos estimularam tanto o acúmulo de água, com o aumento da massa fresca em relação ao controle, como a produção de matéria seca (Figura 1b). Mais uma vez, é demonstrado que os benefícios causados na interação bactéria-planta não dependem do nível de produção in vitro que a linhagem apresenta de produção de AIA ou solubilização de fosfato, pois a linhagem UAGC555 não produziu os maiores índices de fosfato nem de AIA. Segundo Taiz e Zeiger (2004), a ação do AIA, em raízes, é muito importante já que sua principal função é o alongamento das células, o que causa formação de raízes adventícias, que são as principais responsáveis por assimilar água e outros nutrientes presentes no solo.

É importante salientar que, em relação à massa fresca e seca da raiz, nenhum tratamento apresentou efeito negativo, demonstrando claramente o benefício no uso de inóculos bacterianos em vegetais, mesmo sendo utilizados isolados oriundos de outras espécies vegetais. Diante dos resultados, pode-se especular que essas plantas poderiam apresentar maior/menor tolerância ao estresse hídrico devido à presença dessas bactérias, ou que essas bactérias poderiam influenciar a capacidade de realizar a fotossíntese da planta hospedeira, resultando, como observado, no aumento da massa seca da planta.

Em relação à parte aérea das plantas, foi observado que alguns tratamentos apresentaram efeito negativo em relação ao controle, demonstrando que nem todas as linhagens bacterianas inoculadas nas plantas de feijão beneficiaram a parte aérea do vegetal (Figura 1). Esses resultados corroboram com a teoria relatada por Kuklinsky-Sobral et al., 2004; Compant, Clément e Sessitsch (2010), na qual relatam que o genótipo da planta hospedeira, o genótipo da bactéria associada e o nicho de atuação da linhagem bacteriana influenciam no processo de interação bactéria-planta.

O ARDRA tem sido utilizado para estudos de diversidade microbiana associada a vegetais ou a diferentes solos (CHELIUS; TRIPLETT, 2001; KUKLINSKY-SOBRAL et al., 2004; ANDREOTE; LACAVA; AZEVEDO, 2008). Neste trabalho, a amplificação do gene 16S rRNA e sua digestão com enzimas de restrição permitiu a construção da matriz de similaridade pelo coeficiente de Jaccard e do dendrograma pelo 
Índice de similaridade $(\%)$

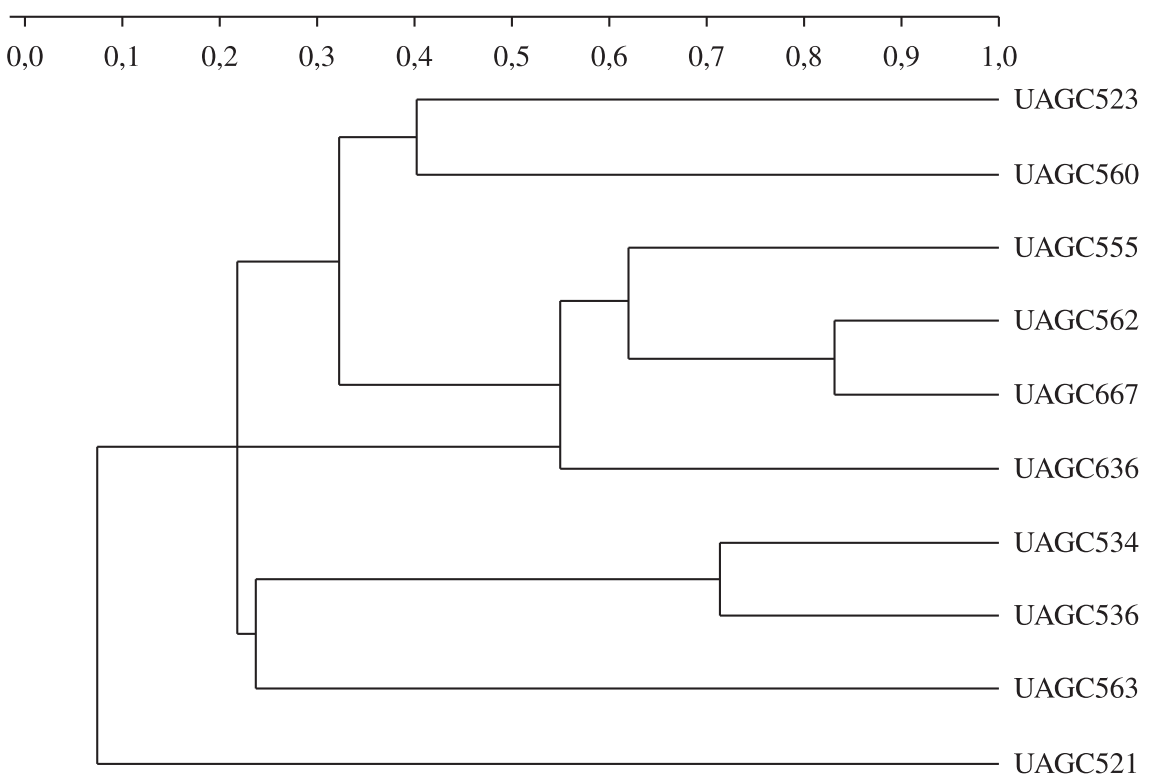

Figura 2. Dendrograma gerado pelo método de UPGMA (Unweighted Pair-Group Method with Arithmetical Average) de agrupamento hierárquico, a partir da matriz de similaridade genética entre as bactérias com características de promoção de crescimento vegetal. O coeficiente de Jaccard foi utilizado para a construção da matriz de similaridade.

método de UPGMA (Figura 2). Foi observada alta diversidade gênica através da formação de dois grandes grupos e uma ramificação isolada contendo uma única linhagem, sugerindo que as linhagens pertencem a gêneros diferentes, uma vez que o ARDRA avaliou a variabilidade da sequência do gene $16 \mathrm{~S}$ rRNA. Provavelmente, foi devida a essa elevada diversidade bacteriana oriunda de cana-de-açúcar, que houve elevada capacidade de produzir AIA em diferentes concentrações, por apresentarem, além da diversidade genética, diferenças contrastantes na funcionalidade fisiológica.

Portanto é possível concluir que bactérias com características de promoção de crescimento vegetal, isoladas de plantas de cana-de-açúcar, influenciaram positivamente o desenvolvimento das raízes de plantas de feijão e que as linhagens apresentaram alta variabilidade genética pela técnica de ARDRA, indicando pertencerem a gêneros diferentes.

\section{Referências}

ANDREOTE, F. D.; LACAVA, P. T.; AZEVEDO, J. L. Diversidade molecular de microorganismos endofíticos. In: FIGUEIREDO, M. V. B. et al. Microrganismos e agrobiodiversidade: o novo desafio para a agricultura. Guaíba: Agrolivros, 2008. p. 233-258.

BODDEY, R. M. et al. Fixação biológica de nitrogênio por bactérias associadas à cana-de-açúcar. Seropédica: EMBRAPACNPBS, 1992. 5 p. (Embrapa-Cnpbs. Comunicado Técnico, n. 6).

CHELIUS, M. K.; TRIPLETT, E. W. The diversity of archaea and bacteria in association with the roots of Zea mays L. Microbial Ecology, v. 41, p. 252-263, 2001.
COMPANT, S.; CLÉMENT, C.; SESSITSCH, A. Plant growth promoting bacteria in the rhizo - and endosphere of plans: their role, colonization, mechanisms involved and prospects for utilization. Soil Biology \& Biochemistry, v. 42, n. 5, p. 669-678, 2010. http:// dx.doi.org/10.1016/j.soilbio.2009.11.024

GYANESWAR, P. et al. Role of soil microorganisms in improving P nutrition of plants. Plant and Soil, v. 245, n. 1, p. 83-93, 2002. http://dx.doi.org/10.1023/A:1020663916259

KUKLINSKY-SOBRAL, J. et al. Isolation and characterization of soybeanassociated bacteria and their potential for plant growth promotion. Environmental Microbiology, v. 6, n. 12, p. 1244-1251, 2004. http://dx.doi.org/10.1111/j.1462 2920.2004.00658.x

MESQUITA, F. R. et al. Linhagens de feijão (Phaseolus vulgaris 1.): composição química e digestibilidade protéica. Ciência e Agrotecnologia, v. 31, n. 4, p. 1114-1121, 2007.

PATTEN, C. L.; GLICK, B. R. Role of Pseudomonas putida indoleacetic acid in development of the host plant root system. Applied and Environmental Microbiology, v. 68, n. 8, p. 37953801, 2002. http://dx.doi.org/10.1128/AEM.68.8.3795-3801.2002

SILVA FILHO, G.N.; VIDOR, C. Solubilização de fosfato por microrganismos na presença de fontes de carbono. Revista Brasileira de Ciência do Solo, v. 24, n. 2, p. 311-319, 2000.

TAIZ, L.; ZEIGER, E. Fisiologia vegetal. 3. ed. Porto Alegre: Guanabara Koogan, 2004. p. 454-460.

TILAK, K. V. B. R. et al. Diversity of plant growth and soil health supporting bacteria. Current Science, v. 89, p. 136-150, 2005.

XAVIER, G. R. et al. Especificidade simbiótica entre rizóbios e acesso de feijão caupi de diferentes nacionalidades. Revista Caatinga, v. 19, p. 25-33, 2006. 